\title{
The AT1/Raf/ERK1/2 signaling pathway is involved in Angiotensin II-enhanced proliferation of hepatic carcinoma cells
}

\author{
R. QI' ${ }^{1}$ C. G. $\mathrm{LEI}^{2}$, Y. X. BAI ${ }^{3}$, N. TANG ${ }^{4}$, X. XING ${ }^{2, *}$ \\ ${ }^{1}$ Affiliated Dalian Friendship Hospital of Dalian Medical University, Dalian, China; ${ }^{2}$ Hepatological Surgery Department, Qingdao Municipal \\ Hospital, Qingdao, China; ${ }^{3}$ Dalian University Affiliated Xinhua Hospital, Dalian, China; ${ }^{4}$ Weifang Medical College, Weifang, China \\ ${ }^{*}$ Correspondence: 521082272@qq.com
}

Received December 13, 2017 / Accepted July 4, 2018

\begin{abstract}
Angiotensin II (Ang II) has been strongly associated with biological behavior in human malignant tumors; nevertheless, its function in hepatic carcinoma growth and progression is still not well understood. This study investigates the effect and mechanism of Ang II on the HepG2 and Hep3B hepatic carcinoma cell lines in vitro. The effect of Ang II on HepG2 and Hep3B cell viability was examined by cell counting kit-8 assay (CCK-8). Quantitative real-time PCR and Western blot analysis detected the expression of angiotensin type 1 and type 2 receptors (AT1 and AT2), total extra-cellular signalregulated kinases 1/2 (ERK1/2), phospho-ERK1/2 (p-ERK1/2) and Bcl-2 and c-Myc. Ang II significantly promoted HepG2 cell proliferation by affecting AT1 and AT2 expression and induced ERK1/2 pathway activation. This was reversed by treating HepG2 and Hep3B cells with AT1 blockers; candesartan, Raf inhibitor sorafenib, and ERK1/2 inhibitor PD98059. Ang II also up-regulated the expression of Bcl-2 and c-Myc in HepG2 cells, and our results suggest that Ang II has a positive role in HepG2 and Hep3B cell proliferation through the AT1/Raf/ERK1/2 signaling pathway.
\end{abstract}

Key words: angiotensin II, Liver cancer, angiotensin type 1 receptor, Raf, extracellular signal-regulated kinase 1/2

Primary liver malignancy is a leading global cause of cancer-related deaths [1]. Approximately 90\% of hepatocellular carcinomas (HCC) arise from chronic inflammation associated with continuous hepatic injury and hepatocyte regeneration [2]. During primary liver cancer development, the inflammation leads to the production of many cytokines, chemokines and growth factors which then enhance cell proliferation, migration and metastasis [3, 4]. Moreover, in recent years, hepatic carcinoma tumorigenesis and development have been strongly associated with genetic mutations, epigenetic modifications and alterations to key signaling pathways [5-7]. Nevertheless, the exact molecular pathogenesis of hepatic carcinoma remains unknown.

Angiogenesis is one of the most critical steps in hepatic carcinoma progression [8-10]. Recent studies have revealed that the renin-angiotensin system (RAS), which regulates a diversity of physiological functions including blood pressure, fluid balance and placental development [11-13], is involved in the regulation of angiogenesis and may have an important role in the progression of hepatic carcinoma $[14,15]$. Angiotensin (Ang) II is the major biologically active effector generated by the RAS system in vasculature, and increasing evidence has shown that Ang II facilitates cancer cell behavior in various human malignancies through cell proliferation, migration and metastasis. While these include breast cancer $[16,17]$, lung cancer [18], and endometrial cancer [19], Ang II function in hepatic carcinoma growth and progression remains poorly understood.

Ang II acts through two different transmembrane receptors in the G protein-coupled receptor family: Ang II type 1 (AT1) and type 2 (AT2) [20]. It has been reported that Ang II stimulates vasoconstriction, aldosterone production, angiogenesis and cell proliferation by the AT1 receptor and produces the opposite effects via the AT2 receptor [12, 21, 22]. It is well known that the AT1 receptor mediates most of the physiological and pathological functions of Ang II by interacting with various $G$ proteins, producing second messengers and also activating multiple intracellular protein kinases [23].

The Ras/Raf/ERK1/2 pathway is often identified as a basic regulatory pathway in the RAS system, and previous breast cancer study has shown that Ang II induces cancer cell proliferation through AT1 receptor-mediated extracellular signal-regulated kinase (ERK) $1 / 2$ phosphorylation; thus suggesting Ang II-AT1-ERK1/2 axis involvement in cancer progression [24]. 
This study treated the HepG2 and Hep3B hepatic carcinoma cell lines with Ang II to further explore its mechanism and effect on cell proliferation in vitro; and our results demonstrated that Ang II can promote HepG2 and Hep3B cell proliferation through AT1/Raf/ERK1/2 signaling. This provides new insight into hepatic carcinoma growth and a putative therapeutic intervention against primary human liver malignancy.

\section{Materials and methods}

Cell line and cell culture. Human hepatocellular carcinoma cell line Hep3B and human hepatoblastoma cell line HepG2 were obtained from the Key Laboratory of Cell Transplantation, Ministry of Health, Dalian, Liaoning, China. Cells were cultured in DMEM (HyClone, South Logan, Utah, USA) supplemented with $10 \%$ fetal calf serum (HyClone), penicillin $(50 \mathrm{IU} / \mathrm{ml})$ and streptomycin $(100 \mu \mathrm{g} / \mathrm{ml})$ in a humidified atmosphere of $5 \% \mathrm{CO}_{2}$ at $37^{\circ} \mathrm{C}$.

Chemical reagents. Ang II was purchased from ApexBio (Houston, TX, USA) and dissolved in distilled water to prepare a stock solution of 1M. Candesartan (\#240626; J\&K Chemical, Beijing, China), Sorafenib Tosylate (HY-10201A; MedChemExpress, Monmouth Junction, NJ, USA) and PD98059 (Cell signaling, Danvers, MA) were dissolved in DMSO. All stock solutions were stored at $-20^{\circ} \mathrm{C}$.

Cell Counting Kit-8 (CCK-8) assay. Five thousand cells/ well were plated in 96-well plates and incubated for 24 hours. Cells were then exposed to gradually increased concentration of Ang II to examine its effect on the cell growth $\left(1 \times 10^{-8}\right.$, $1 \times 10^{-7}, 1 \times 10^{-6}, 1 \times 10^{-5}$, and $1 \times 10^{-4} \mathrm{~mol} / 1$ - in 8 replicates). Cells were incubated with CCK-8 solution at $37^{\circ} \mathrm{C}$ for an additional 1.5 hours 24 and 48 hours after treatment, (7sea biotech, Shanghai, China). The absorbance (optical density, OD) was measured at $450 \mathrm{~nm}$ wavelength by microplate reader (SpectraMax M4, MolecularDevices, Cal, USA).

Quantitative real-time PCR. Total RNA was isolated by Trizol reagent (Cwbio, Shanghai, China) and reversely transcribed to synthesize cDNA using a reverse transcription kit (TakaRa, Japan). Real-time PCR was performed using the following primers: AT1: 5'-AGACAGATGACGGCTGCTCG-3' (forward); 5'-AACAATCTGGAACTCTCATCTCCTG-3' (reverse); AT2:5'-CATTGACCTGGCACTTCCTT-3' (forward); 5'-ACATGCATTTTGCTCTCACG-3' (reverse); Bcl-2: 5'-GGATGCCTTTGTGGAACTGT-3' (forward), 5'-AGCCTGCAGCTTTGTTTCAT-3' (reverse); c-Myc: 5'-TTCGGGTAGTGGAAAACCCAG-3' (forward), 5'-CAGCAGCTCGAATTTCTTCC-3' (reverse); GAPDH: 5'-TGGTATCGTGGAAGGACTCATGAC-3' (forward), 5'-ATGCCAGTGAGCTTCCCGTTCAGC -3' (reverse). Data is quantified by the $2^{-\Delta \Delta C t}$ method.

Western blot assay. Cells were lysed with lysis buffer on ice. Cell lysates were collected by centrifugation at $16,000 \mathrm{~g}$ for $20 \mathrm{~min}$, followed by heating at $95^{\circ} \mathrm{C}$ for $5 \mathrm{~min}$ in a loading buffer. Twenty $\mu$ g of proteins were separated by $10 \%$ sodium dodecyl sulfate-polyacrylamide gel electrophoresis and then transferred to polyvinylidene difluoride membranes, followed by blocking for 2 hours in 5\% non-fat milk in Trisbuffered saline containing Tween 20 (TBST). The membranes were then incubated with primary antibody against GAPDH (Abcam, Cambridge, UK), p44/42 MAPK (ERK1/2; Cell Signaling, Danvers, MA), phospho-MAPK (p-ERK1/2; Cell Signaling Technology, Danvers, MA, USA), AT1 (Abcam, Cambridge, UK) or AT2 (Abcam, Cambridge, UK) at $4{ }^{\circ} \mathrm{C}$ overnight. This was followed by TBST rinses and incubation with HRP-conjugated secondary antibody (Cell Signaling Technology, Danvers, MA, USA) for 2 hours at room temperature. The chemiluminescent signals were detected using ECL substrate (Fermentas, Waltham, MA, USA) and quantified using ImageJ software.

Statistical analysis. All experiments were run in triplicate. Data is expressed as the mean \pm standard deviation. One-way analysis of variance followed by the Least Significant Difference post hoc test compared multiple groups. Statistical significance was assessed using SPSS 17.0 software (SPSS, Chicago, IL, USA), and p-value $<0.05$ was considered statistically significant.

\section{Results}

Ang II promotes HepG2 and Hep3B cells proliferation. To evaluate the effect of Ang II on cells proliferation, HepG2 and Hep3B cells were treated with Ang II at various concentrations $\left(1 \times 10^{-8}, 1 \times 10^{-7}, 1 \times 10^{-6}, 1 \times 10^{-5}\right.$, and $\left.1 \times 10^{-4} \mathrm{~mol} / \mathrm{l}\right)$ for 24 and $48 \mathrm{~h}$, respectively. HepG 2 and Hep3B cells treated with $1 \times 10^{-7} \mathrm{~mol} / 1$ or higher doses of Ang II for $24 \mathrm{~h}$ had significant increase in cell viability compared with the control (Figures 1A, B). Following 48 h of Ang II treatment, even at the lowest dose of $1 \times 10^{-8} \mathrm{~mol} / \mathrm{l}$, the viability of the two cell types was significantly increased compared to controls (Figure 1C, D). These results indicate that Ang II promotes HepG2 and Hep3B cell proliferation. These two cell lines had highest viability with $10^{-6} \mathrm{~mol} / \mathrm{l}$ for $48 \mathrm{~h}$, therefore $10^{-6} \mathrm{~mol} / \mathrm{l}$ was chosen in the following experiment.

The effect of Ang II on HepG2 and Hep3B cell proliferation was reversed after treating cells with AT1 receptor blocker, Raf inhibitor and ERK1/2 signaling inhibitors. To verify if the AT1/Raf/ERK1/2 pathway is involved in HepG2 and Hep3B cell proliferation regulation, the AT1 receptor, Raf signaling, and ERK signaling were blocked using the AT1 receptor blocker candesartan $\left(1 \times 10^{-7} \mathrm{~mol} / \mathrm{l}\right.$, pre-process $1.5 \mathrm{~h})$, Raf inhibitor sorafenib $\left(1 \times 10^{-7} \mathrm{~mol} / \mathrm{l}\right.$, pre-process $1.5 \mathrm{~h})$, and ERK1/2 inhibitor PD98059 $\left(1 \times 10^{-7} \mathrm{~mol} / \mathrm{l}\right.$, pre-process $1.5 \mathrm{~h})$, respectively. Each inhibitor/blocker significantly reduced the effects of Ang II on both HepG2 and Hep3B cell growth. In addition, both cell lines showed similar trends (Figure 2). Due to the high similarity of drug response between the two cell lines, we believe the related signaling pathway exists in both cell lines and has the same function. We therefore selected HepG2 cells for the following 
A

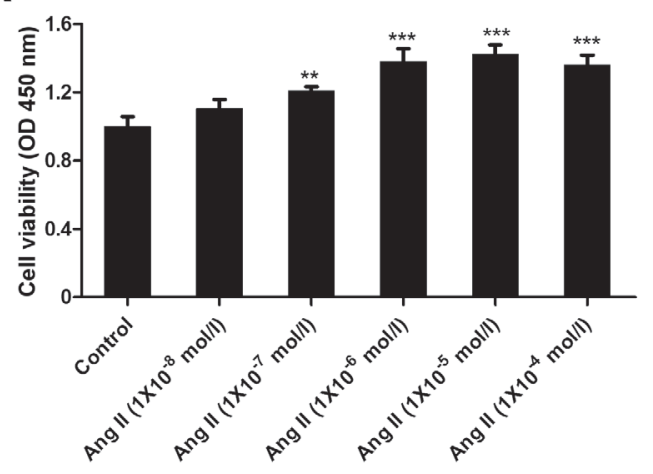

C

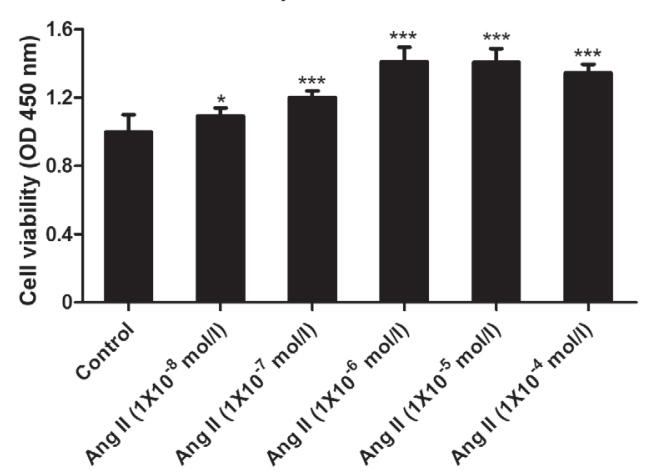

B

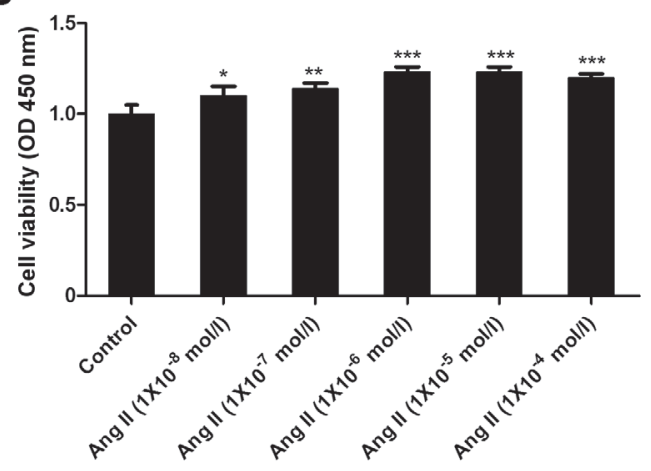

D

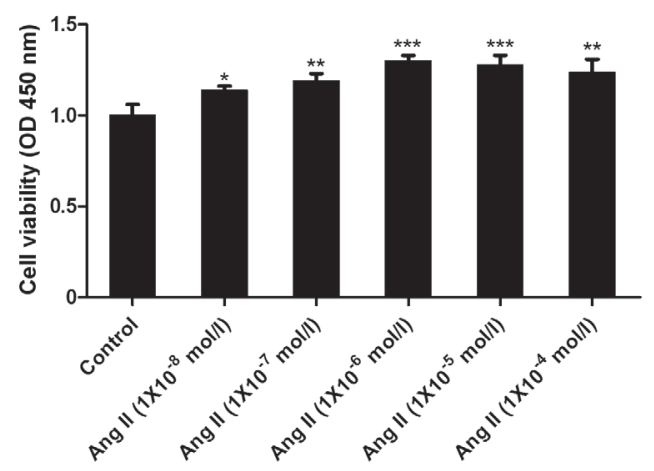

Figure 1. Ang II promoted cell proliferation in HepG2 and Hep3B cells. HepG2 (A, B) and Hep3B (C, D) cells were treated with increasing concentrations of Ang II for $24 \mathrm{~h}(\mathrm{~A}, \mathrm{C})$ and $48 \mathrm{~h}(\mathrm{~B}, \mathrm{D})$, respectively and then cell viability was measured using CCK-8 assay. Data is expressed as the mean \pm SD; ${ }^{*} \mathrm{p}<0.05 ;{ }^{* *} \mathrm{p}<0.01 ;{ }^{* *} \mathrm{p}<0.001$ vs. control; $\mathbf{n}=8$. Ang II, Angiotensin II; CCK-8, cell counting kit-8; SD, standard deviation.
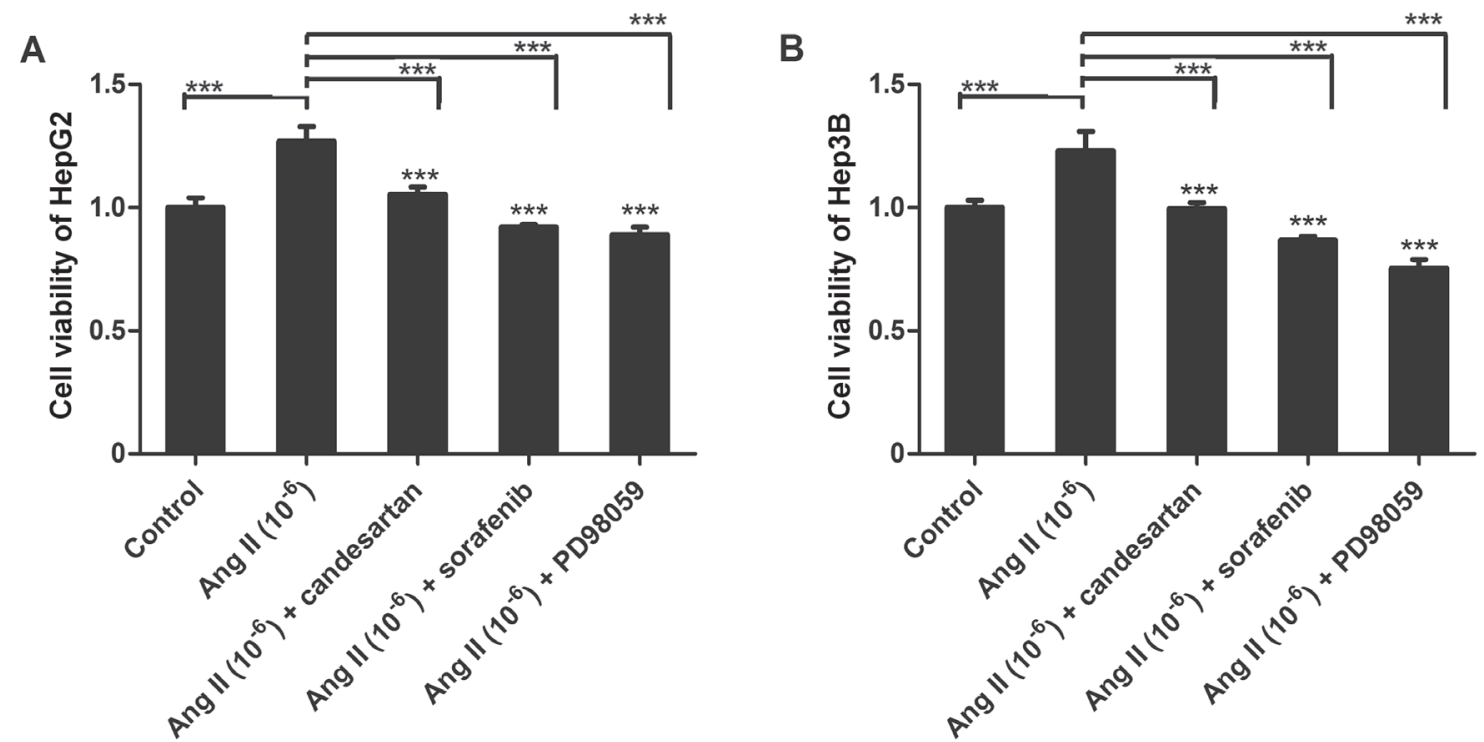

Figure 2. The blocker of AT1 receptor, Raf inhibitor and inhibitors of ERK1/2 signaling reversed the effects of Ang II on HepG2 and Hep3B cell proliferation. HepG2 (A) and Hep3B (B) cells were pre-treated $(1.5 \mathrm{~h})$ with $1 \times 10^{-7} \mathrm{~mol} / \mathrm{l}$ concentration of AT1 receptor blocker candesartan, Raf inhibitor sorafenib, and ERK inhibitor PD 98059 followed by $1 \mu \mathrm{mol} / \mathrm{l}$ Ang II treatment for $24 \mathrm{~h}$, respectively. The cell viability of both cell lines was measured by CCK-8 assay $(n=8)$. Data is expressed as the mean $\pm S D ;{ }^{* *} p<0.01 ;{ }^{* *} p<0.001$ vs. control. Ang II, Angiotensin II; ERK, extracellular-signal-regulated kinase; p-ERK, phosphorylated-ERK; SD, standard deviation. 
experiments. Figure 3 shows that compared with the Ang II-only treated group, the protein expression of $\mathrm{p}$-ERK1/2 was significantly suppressed following the addition of each inhibitor/blocker, thus suggesting that the AT1/Raf/ERK1/2 axis is critically important for Ang II-induced HepG2 and Hep3B cell growth.

Ang II induces phosphorylation of ERK1/2 in HepG2 cells. ERK1/2 has an important role in the regulation of cancer cell survival and proliferation [25-27]. To further investigate the signaling pathway contributing to Ang II-induced HepG2 cell proliferation, we examined the time-course expression of phospho-ERK1/2 in response to Ang II. As shown in Figure 4, after treatment with $1 \times 10^{-6} \mathrm{~mol} / \mathrm{l}$ Ang II, the protein expression of p-ERK1/2 markedly increased 5 minutes after the treatment, and then gradually decreased. The expression of total ERK remained unchanged. The combined data suggests that p-ERK1/2 activation is most likely responsible for Ang II-induced HepG 2 cell proliferation.

Ang II induces the expression of the Ang II receptors AT1 and AT2 in HepG2 cells. Since both HepG2 and Hep3B cell lines obtained the same result in previous experiments, we selected HepG 2 cells treated with Ang II to examine the AT1 and AT2 receptors expression and investigate the signaling mechanism responsible for their Ang II-induced proliferation. As shown in Figure 5, both mRNA and protein expression of the AT1 receptor were significantly increased after 24-hour treatment with Ang II, thus suggesting that the AT1 receptor has a potential role in mediating Ang II-induced
A

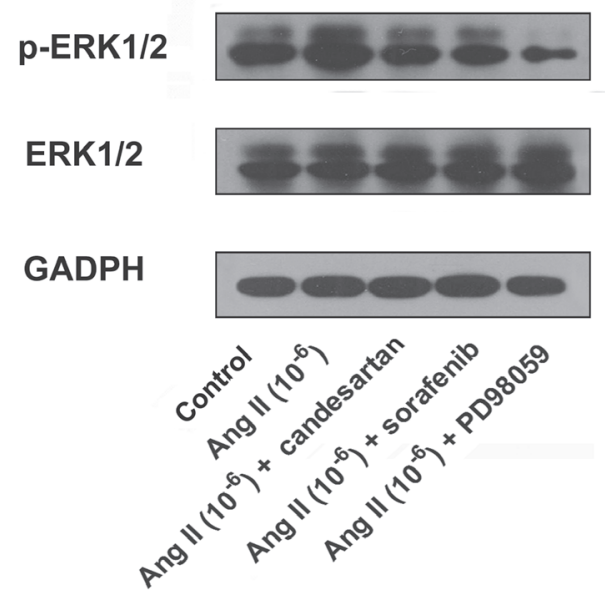

B

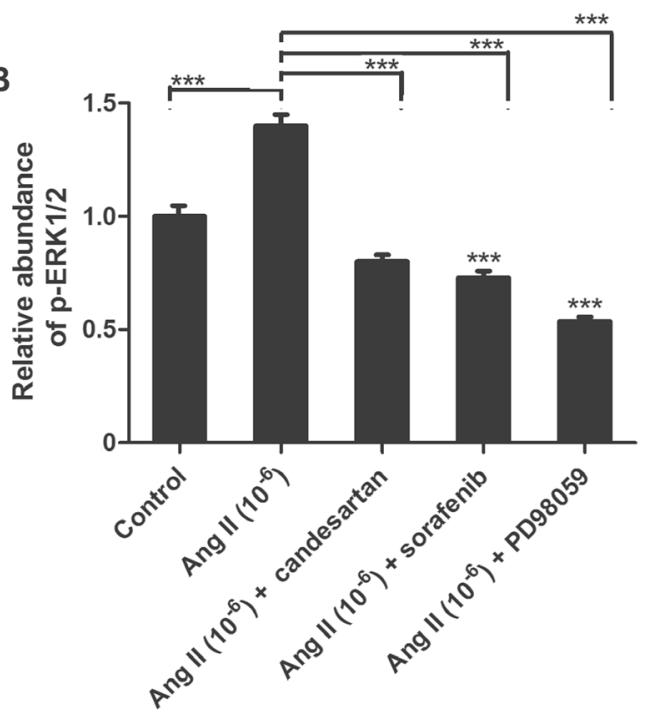

Figure 3. PD98059, sorafenib and the blocker of AT1 receptor reversed the effects of Ang II induced phosphorylation of ERK1/2 in HepG2 cells. HepG2 cells were pre-treated for $1.5 \mathrm{~h}$ with AT1 receptor blocker candesartan $\left(1 \times 10^{-7} \mathrm{~mol} / \mathrm{l}\right)$, Raf inhibitor sorafenib $\left(1 \times 10^{-7} \mathrm{~mol} / \mathrm{l}\right)$, and ERK inhibitor PD98059 $\left(1 \times 10^{-7} \mathrm{~mol} / \mathrm{l}\right)$ prior to $1 \mu \mathrm{mol} / 1 \mathrm{Ang}$ II $24 \mathrm{~h}$ treatment, respectively. Western blot analysis detected GAPDH, total ERK1/2 and p-ERK1/2 in HepG2 cells. Data is expressed as the mean $\pm \mathrm{SD} ;{ }^{* *} \mathrm{p}<0.01 ;{ }^{* * *} \mathrm{p}<0.001$ vs. control. Ang II, Angiotensin II; ERK, extracellular-signal-regulated kinase; p-ERK, phosphorylated-ERK; SD, standard deviation.

A

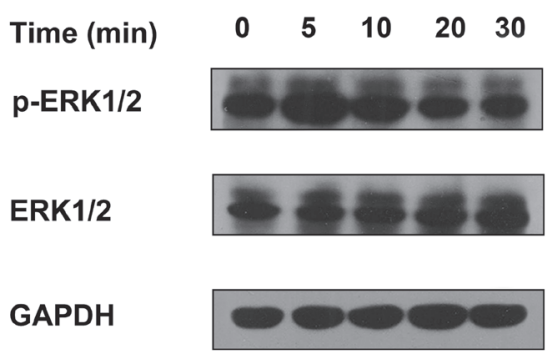

B

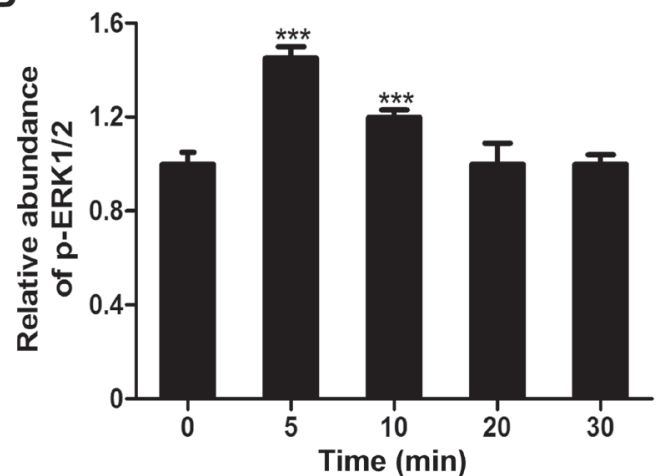

Figure 4. Ang II induced phosphorylation of ERK1/2 in HepG2 cells. Western blot analysis detected GAPDH, total ERK1/2 and p-ERK1/2 in HepG2 cells at $0,5,10,20$, and $30 \mathrm{~min}$ after treatment with $1 \mu \mathrm{mol} / 1$ Ang II. Data of quantification (right panel) is expressed as the mean $\pm S D$; ${ }^{* *}<<0.01$; ${ }^{* * *} \mathbf{p}<\mathbf{0 . 0 0 1}$ vs. control; $\mathbf{n}=\mathbf{3}$. Ang II, Angiotensin II; ERK, extracellular-signal-regulated kinase; $\mathbf{p}$-ERK, phosphorylated-ERK; SD, standard deviation. 
A
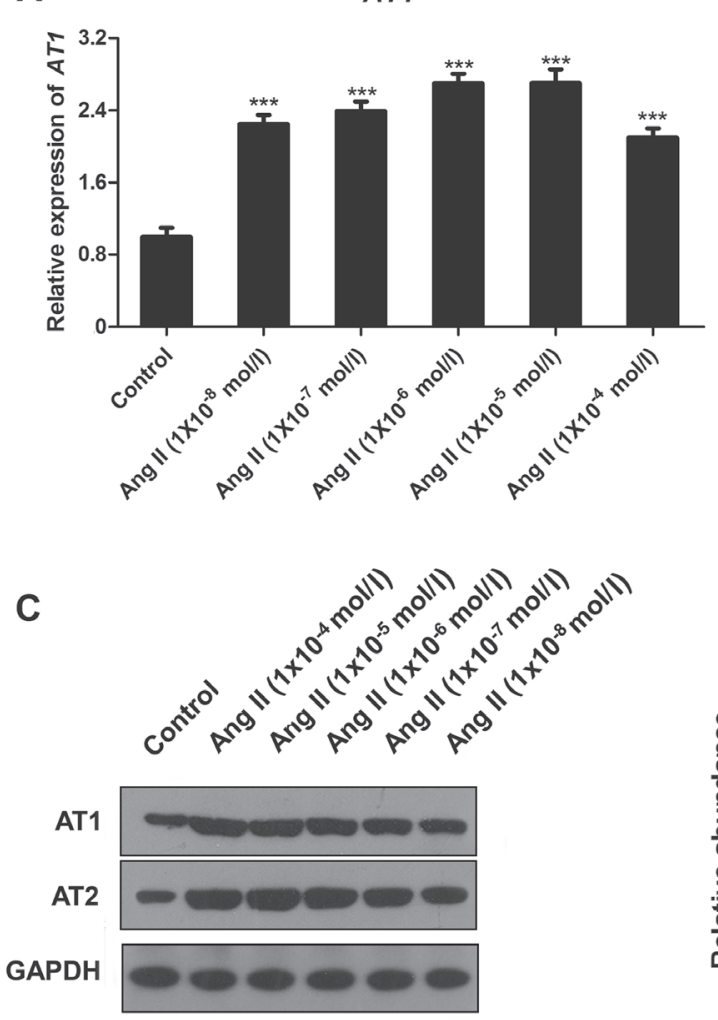

B

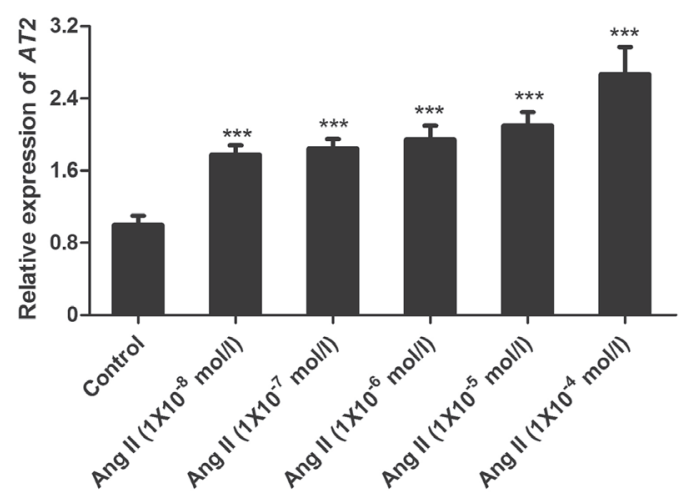

D

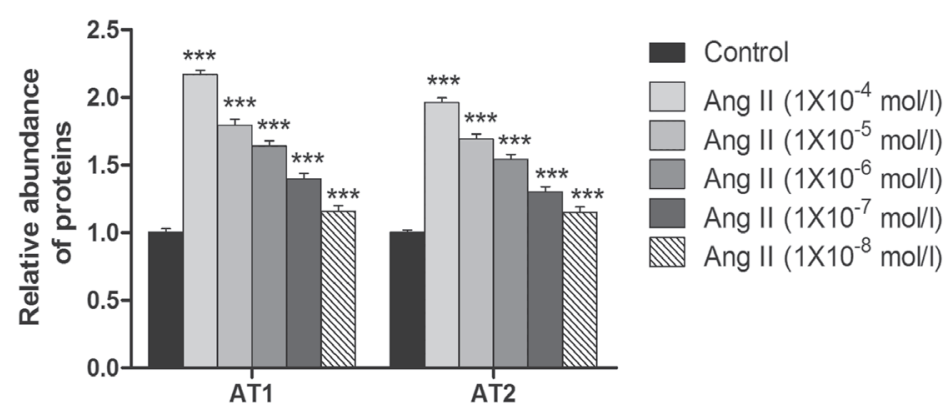

Figure 5. Ang II induced the expression of Ang II receptors (AT1 and AT2) in HepG2 cells. Cells were treated with $1 \mu \mathrm{mol} / 1$ Ang II for 24 h. The mRNA expression of AT1 (A) and AT2 (B) was detected by qPCR and Western blot analysis and quantification for the protein expression of AT1 and AT2 (C, D) were performed. Data is expressed as the mean $\pm \mathrm{SD} ;{ }^{* *} \mathbf{p}<0.01 ;{ }^{* * *} \mathrm{p}<0.001$ vs. control; $\mathbf{n}=3$. Ang II, Angiotensin II; AT1, angiotensin receptor type 1; AT2, angiotensin receptor type $2 ; \mathrm{SD}$, standard deviation.

HepG2 cell proliferation. The coincidently elevated AT2 receptor expression is possibly an instinctive response to Ang II stimulation, because AT2 activation participates in cancer cell apoptosis [28-30].

Ang II induces the mRNA expression of c-Myc and Bcl-2 in HepG2 cells. Bcl-2 and c-Myc are two important proteins commonly over-expressed in hepatic carcinoma and they participate in regulating cell growth, differentiation and apoptosis $[31,32]$. ERK1/2 is an up-stream regulator of both Bcl-2 and c-Myc [33, 34]. To further confirm the involvement of ERK1/2 signaling in Ang II-mediated HepG2 cell proliferation, we examined the mRNA expression of down-stream Bcl-2 and c-Myc. Both c-Myc and Bcl-2 were up-regulated 6 hours post-Ang II treatment, suggesting that the Ang II-induced HepG2 cell proliferation is due to $\mathrm{Bcl}-2$ and c-Myc up-regulation via ERK activation (Figure 6).

\section{Discussion}

Herein, we investigated Ang II effect on human hepatic carcinoma cell proliferation. We identified the signaling pathway and down-stream genes contributing to Ang II-induced cell proliferation and results elucidated potential novel therapeutic targets for primary liver cancer treatment.

Hep3B and HepG2 cells were treated with Ang II ranging from $10 \mathrm{nmol} / \mathrm{l}$ to $100 \mu \mathrm{mol} / \mathrm{l}$ and both cell lines had the same drug response. These amounts were the lowest effective doses of Ang II that significantly increased the cell viability at 24 and 48 hours, respectively (Figure 1). There was a dose-dependent response with doses $\leq 10 \mu \mathrm{mol} / \mathrm{l}$ in 24-hour treatment and $\leq 1 \mu \mathrm{mol} / 1$ in 48 -hour treatment. The loss of dose-response effect above $10 \mu \mathrm{mol} / \mathrm{l}$ or $1 \mu \mathrm{mol} / \mathrm{l}$ of Ang II occurred because of the wide range in dosage (10-fold).

Ang II exerts its biological functions through the AT1 and AT2 receptors. Although the AT1 receptor is considered more important [23], the AT2 receptor role is not negligible. In contrast to AT1, the AT2 receptor activation exerts an inhibitory effect on cell proliferation and a stimulatory effect on apoptosis in various cell lines. These include cardiomyocytes, endothelial cells, vascular smooth muscle cells, fibroblasts and prostate and lung cancer cells [29, 30, 35-37]. 
A

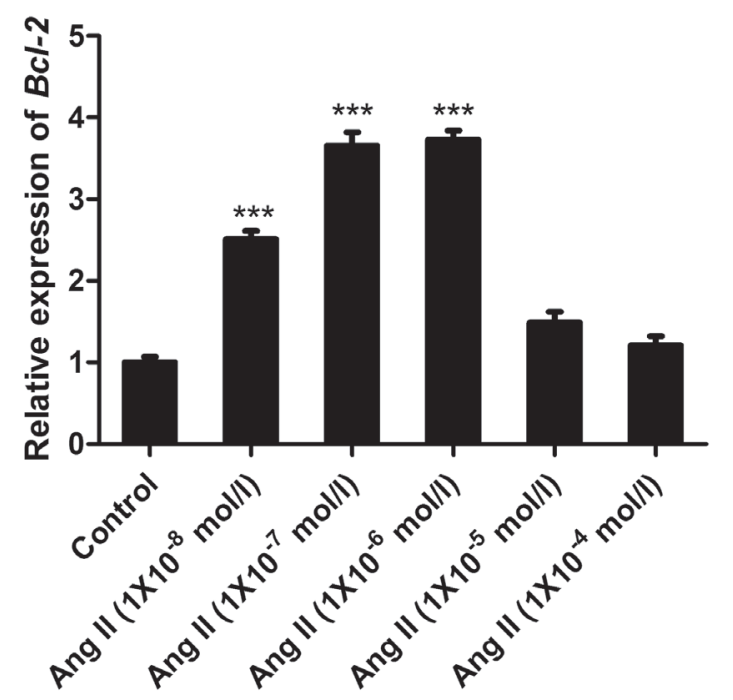

B

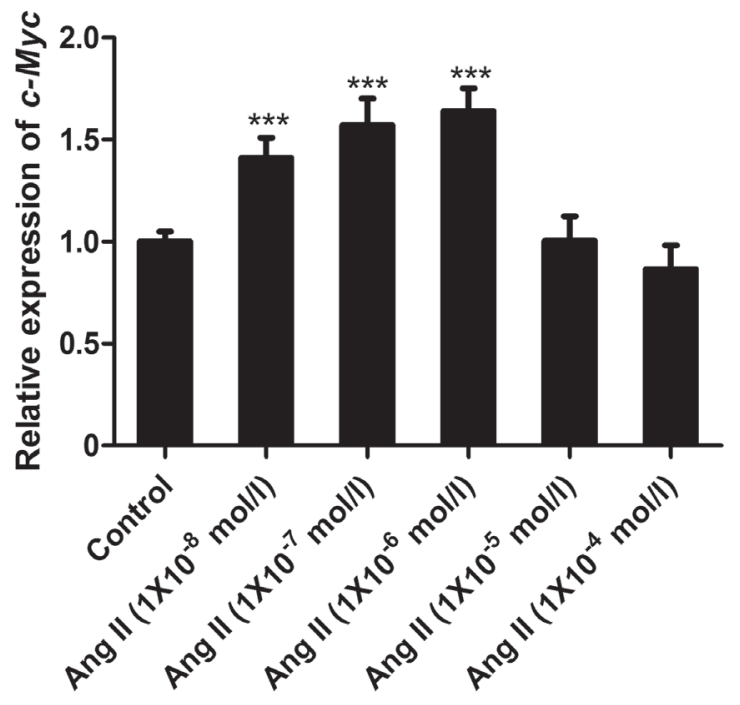

Figure 6. Ang II upregulated the mRNA expression of Bcl-2 and c-Myc in HepG2 cells. Cells were treated with $1 \mu \mathrm{mol} / \mathrm{l}$ Ang II for $24 \mathrm{~h}$. The mRNA expression of Bcl-2 (right panel) and c-Myc (left panel) was detected by qPCR. Data is expressed as the mean $\pm \mathrm{SD}$; ${ }^{\star *}$ p $<0.01$; ${ }^{\star * \star}$ p $<0.001$ vs. control; n=3. Ang II, Angiotensin II; SD, standard deviation.

Additional research included;

Wang et al. found that Ang II increased the expression of AT2 but not AT1 at both the transcriptional and translational levels in vascular smooth muscle cells [38].

Miura et al. suggested that stimulation of the AT2 receptor by Ang II is not required for induction of apoptosis; but the receptor protein expression-level is critical [39].

Du et al. suggest that Ang II promotes cell proliferation in HepG2 cells by high expression of AT1 and AT2 proteins [40].

Herein, we established that in addition to the AT1 receptor, AT2 receptor expression was dramatically enhanced by Ang II in a dose-dependent manner (Figure 5). But our results show that candesartan significantly inhibited Ang II-induced cell proliferation, and this demonstrates that high AT2 receptor expression is not essential in promoting HepG2 proliferation (Figure 2). In view of the suppressive effect of AT2 on cell proliferation, highly expressed AT2 receptors may be associated with decreased proliferation as Ang II concentration increases. In addition, $\mathrm{Du}$ et al. reported that moderately enhanced AT2 expression increases HCC cell proliferation in vitro and the growth of HCC tumors in vivo, whereas a high dose of ectopic over-expression of AT2 in hepatic carcinoma cell lines induces apoptosis and inhibits cell proliferation [41].

Figure 5 shows that $1 \mu \mathrm{mol} / \mathrm{l}$ of Ang II strongly enhanced cell proliferation, but the AT1 protein level was not as high when other concentrations were used. We believe that, although the AT1 receptors are constantly over-expressed, AT2 receptor over-expression inhibits cell proliferation in the high-concentration angiotensin-treated group. Therefore,
AT2 function in cell proliferation regulation may depend on the environmental contexts that control AT2 expression. However, the precise mechanism underlying the dual role of AT2 in hepatic carcinoma cell growth is still not fully understood, so our investigation of the mechanisms involved in AT2 hepatocyte proliferation inhibition could well provide a novel target for the treatment of hepatocellular carcinoma.

It is generally accepted that the ERK1/2 signaling pathway is activated in tumor cells, and that inhibiting this signaling is a therapeutic strategy in tumor treatment [42]. Hence, ERK1/2 activity was examined in Ang II-treated HepG2 cells, and results establish that AT1/Raf/ERK1/2 signaling activity is significantly enhanced by Ang II. This is supported by Cell Counting Kit-8 (Figures 1,2) and the markedly elevated levels of p-ERK1/2 (Figure 4).

Similar results were also observed in other cancer cells [24]; and it is noteworthy that although we used candesartan, sorafenib and PD98059 to suppress the level of p-ERK1/2, cell viability did not correspond with protein levels.

The regulation of cell proliferation is a complex and multipathway process, and we suggest involving the AT1 receptor and Raf protein in other signal pathways that regulate cell proliferation. In support, Yuanyuan et al. demonstrated that angiotensin II enhanced HepG2 cell line proliferation through the AT1/PKC/NF-kB signaling pathway [43]. While AT1 receptors promote cell proliferation through at least the Raf/ERK1/2 and PAC/NF/kB pathways, the duration of each drug's efficacy is different and this may be another important reason for this phenomenon. In contrast, the candesartan AT1 blocker, Raf inhibitor sorafenib and ERK inhibitor PD98059 all reverse Ang II-mediated effects, thus 
indicating that Ang II regulates HepG2 cell growth at least partly through AT1/Raf/ERK1/2 signaling (Figure 2). In addition, Hep3B is derived from hepatocellular carcinoma and its biological behavior is similar to HepG2 (Figures 1,2). Further, our experiments determined similar drug response in both cells and therefore we believe that the AT1/Raf/ ERK1/2 signaling pathway is present in both cell lines and has the same biological function.

Activated ERK phosphorylates hundreds of down-stream target molecules, including c-Jun, c-Myc, Bcl-2 and Bax, and it exerts diverse effects on cell proliferation, differentiation, and apoptosis [44]. Herein, we identified Bcl-2 and c-Myc as two down-stream targets of AT1/Raf/ERK1/2 signaling (Figure 6), and this suggests that these genes are potential therapeutic targets in hepatic carcinoma. However, extensive in vivo studies are required to develop these agents into anti-Ang II drugs or vaccines against proteins. Moreover, although the biological functions of the Bcl-2 family remain controversial, agents targeting the Bcl-2 family are already being used in clinical trials [32] and a small molecule compound targeting c-Myc is also in phase II clinical trials to fight neuro-endocrine carcinoma. [45].

In conclusion, our data demonstrated that Ang II promoted HepG2 and Hep3B cell proliferation in vitro. Mechanically, the expression of AT1, AT2, and p-ERK1/2 was significantly up-regulated by Ang II, thus suggesting that ERK signaling is responsible for Ang II-induced cell proliferation. Furthermore, we established that AT1 receptor blocking and ERK1/2 signaling inhibition reversed the effects of Ang II on HepG2 and Hep3B cell proliferation, thus indicating Ang II mediation of hepatic carcinoma cell proliferation via the AT1/Raf/ ERK1/2 pathway. Finally, we identified Bcl-2 and c-Myc as two down-stream targets of the AT1/Raf/ERK1/2 pathway.

Acknowledgements: This study was supported by the Funding Project of Science and Technology Development of Shinan District (2014-14-037-YY). We thank the Key Laboratory of Cell Transplantation, Ministry of Health, Dalian, Liaoning, China for providing the cell line.

\section{References}

[1] BALOGH J, VICTOR D 3RD, ASHAM EH, BURROUGHS SG, BOKTOUR $M$ et al. Hepatocellular carcinoma: a review. J Hepatocell Carcinoma 2016; 3: 41-53. https://doi. org/10.2147/JHC.S61146

[2] BISHAYEE A. The role of inflammation and liver cancer. Adv Exp Med Biol 2014; 816: 401-435. https://doi. org/10.1007/978-3-0348-0837-8_16

[3] COUSSENS LM, WERB Z. Inflammation and cancer. Nature 2002; 420: 860-867.

[4] HEIKENWALDER M, PIKARSKY E. Learning the Roles of the Hepatic Adaptive Immune System in Hepatocellular Carcinoma-Nature's Guide for Successful Cancer Immunotherapy. Semin Liver Dis 2017; 37: 210-218. https://doi. org/10.1055/s-0037-1606255
[5] WHITTAKER S, MARAIS R, ZHU AX. The role of signaling pathways in the development and treatment of hepatocellular carcinoma. Oncogene 2010; 29: 4989-5005. https:// doi.org/10.1038/onc.2010.236

[6] DHANASEKARAN R, BANDOH S, ROBERTS LR. Molecular pathogenesis of hepatocellular carcinoma and impact of therapeutic advances. F1000Res 2016; 5. https://doi. org/10.12688/f1000research.6946.1

[7] XIE YX, LIAO R, PAN L, DU CY. ERK pathway activation contributes to the tumor-promoting effects of hepatic stellate cells in hepatocellular carcinoma. Immunol Lett 2017; 188: 116-123. https://doi.org/10.1016/j.imlet.2017.06.009

[8] ZHU AX, DUDA DG, SAHANI DV, JAIN RK. HCC and angiogenesis: possible targets and future directions. Nat Rev Clin Oncol 2011; 8: 292-301. https://doi.org/10.1038/nrclinonc. 2011.30

[9] RAOUL JL, GILABERT M, ADHOUTE X, EDELINE J. An in-depth review of chemical angiogenesis inhibitors for treating hepatocellular carcinoma. Expert Opin Pharmacother 2017; 18: 1467-1476. https://doi.org/10.1080/14656566. 2017.1378346

[10] YUKSEL S, BOYLU AKYERLI C, CENGIZ YAKICIER M. Angiogenesis, Invasion, and Metastasis Characteristics of Hepatocellular Carcinoma. J Gastrointest Cancer 2017. https://doi.org/10.1007/s12029-017-9962-5

[11] SPARKS MA, CROWLEY SD, GURLEY SB, MIROTSOU M, COFFMAN TM. Classical Renin-Angiotensin system in kidney physiology. Compr Physiol 2014; 4: 1201-1228. https://doi.org/10.1002/cphy.c130040

[12] WANG Y, LUMBERS ER, SYKES SD, PRINGLE KG. Regulation of the Renin-Angiotensin System Pathways in the Human Decidua. Reprod Sci 2015; 22: 865-872. https://doi. org/10.1177/1933719114565029

[13] FYHRQUIST F, SAIJONMAA O. Renin-angiotensin system revisited. J Intern Med 2008; 264: 224-236. https://doi. org/10.1111/j.1365-2796.2008.01981.x

[14] YE G, QIN Y, LU X, XU X, XU S et al. The association of renin-angiotensin system genes with the progression of hepatocellular carcinoma. Biochem Biophys Res Commun 2015; 459: 18-23. https://doi.org/10.1016/j.bbrc.2015.02.030

[15] YOSHIJI H, NOGUCHI R, IKENAKA Y, KAJI K, AIHARA $\mathrm{Y}$ et al. Impact of renin-angiotensin system in hepatocellular carcinoma. Curr Cancer Drug Targets 2011; 11: 431-441.

[16] RODRIGUES-FERREIRA S, ABDELKARIM M, DILLENBURG-PILLA P, LUISSINT AC, DI-TOMMASO A et al. Angiotensin II facilitates breast cancer cell migration and metastasis. PLoS One 2012; 7: e35667. https://doi. org/10.1371/journal.pone.0035667

[17] LI Z, ZOU D, MA X, CHEN J, SHI X et al. Epidemiology of peptic ulcer disease: endoscopic results of the systematic investigation of gastrointestinal disease in China. Am J Gastroenterol 2010; 105: 2570-2577. https://doi.org/10.1038/ ajg.2010.324

[18] TAWINWUNG S, NINSONTIA C, CHANVORACHOTE P. Angiotensin II Increases Cancer Stem Cell-like Phenotype in Lung Cancer Cells. Anticancer Res 2015; 35: 4789-4797. 
[19] NOWAKOWSKA M, MATYSIAK-BURZYNSKA Z, KOWALSKA K, PLUCIENNIK E, DOMINSKA K et al. Angiotensin II promotes endometrial cancer cell survival. Oncol Rep 2016; 36: 1101-1110. https://doi.org/10.3892/or.2016.4887

[20] RODRIGUES-FERREIRA S, NAHMIAS C. G-protein coupled receptors of the renin-angiotensin system: new targets against breast cancer? Front Pharmacol 2015; 6: 24. https:// doi.org/10.3389/fphar.2015.00024

[21] DORIS PA. Renal proximal tubule sodium transport and genetic mechanisms of essential hypertension. J Hypertens 2000; 18: 509-519.

[22] HAKAM AC, SIDDIQUI AH, HUSSAIN T. Renal angiotensin II AT2 receptors promote natriuresis in streptozotocininduced diabetic rats. Am J Physiol Renal Physiol 2006; 290: F503-508. https://doi.org/10.1152/ajprenal.00092.2005

[23] HIGUCHI S, OHTSU H, SUZUKI H, SHIRAI H, FRANK GD et al. Angiotensin II signal transduction through the AT1 receptor: novel insights into mechanisms and pathophysiology. Clinical science 112: 417-428, 2007. Clin Sci (Lond) 2007; 112: 417-428. https://doi.org/10.1042/CS20060342

[24] MUSCELLA A, GRECO S, ELIA MG, STORELLIC, MARSIGLIANTE S. PKC-zeta is required for angiotensin II-induced activation of ERK and synthesis ofC-FOS in MCF-7 cells. JCell Physiol 2003; 197: 61-68. https://doi.org/10.1002/jcp.10336

[25] BUTLER DE, MARLEIN C, WALKER HF, FRAME FM, MANN VM et al. Inhibition of the PI3K/AKT/mTOR pathway activates autophagy and compensatory Ras/Raf/MEK/ ERK signalling in prostate cancer. Oncotarget 2017; 8: 56698-56713. https://doi.org/10.18632/oncotarget.18082

[26] ZHOU RT, HE M, YU Z, LIANG Y, NIE Y et al. Baicalein inhibits pancreatic cancer cell proliferation and invasion via suppression of NEDD9 expression and its downstream Akt and ERK signaling pathways. Oncotarget 2017; 8: 5635156363. https://doi.org/10.18632/oncotarget.16912

[27] TSUBOI M, TANIUCHI K, SHIMIZU T, SAITO M, SAIBARA T. The Transcription Factor HOXB7 Regulates ERK Kinase Activity and Thereby Stimulates the Motility and Invasiveness of Pancreatic Cancer Cells. J Biol Chem 2017; 292: 17681-17702. https://doi.org/10.1074/jbc.M116.772780

[28] LUTZEN U, ZHAO Y, LUCHT K, ZUHAYRA M, HEDDERICH J et al. Activation of the cell membrane angiotensin AT2 receptors in human leiomyosarcoma cells induces differentiation and apoptosis by a PPARgamma - dependent mechanism. Neoplasma 2017; 64: 395-405. https://doi. org/10.4149/neo_2017_310

[29] LI H, QI Y, LI C, BRASETH LN, GAO Y et al. Angiotensin type 2 receptor-mediated apoptosis of human prostate cancer cells. Mol Cancer Ther 2009; 8: 3255-3265. https://doi. org/10.1158/1535-7163.MCT-09-0237

[30] PICKEL L, MATSUZUKA T, DOI C, AYUZAWA R, MAURYA DK et al. Over-expression of angiotensin II type 2 receptor gene induces cell death in lung adenocarcinoma cells. Cancer Biol Ther 2010; 9: 277-285. https://doi.org/10.4161/ cbt.9.4.10643

[31] LIN CP, LIU CR, LEE CN, CHAN TS, LIU HE. Targeting c-Myc as a novel approach for hepatocellular carcinoma. World J Hepatol 2010; 2: 16-20. https://doi.org/10.4254/wjh. v2.i1.16
[32] KANG MH, REYNOLDS CP. Bcl-2 inhibitors: targeting mitochondrial apoptotic pathways in cancer therapy. Clin Cancer Res 2009; 15: 1126-1132. https://doi.org/10.1158/10780432.CCR-08-0144

[33] LUANPITPONG S, CHANVORACHOTE P, STEHLIK C, TSE W, CALLERY PS et al. Regulation of apoptosis by Bcl-2 cysteine oxidation in human lung epithelial cells. Mol Biol Cell 2013; 24: 858-869. https://doi.org/10.1091/mbc.E12-100747

[34] MARAMPON F, CICCARELLI C, ZANI BM. Down-regulation of c-Myc following MEK/ERK inhibition halts the expression of malignant phenotype in rhabdomyosarcoma and in non muscle-derived human tumors. Mol Cancer 2006; 5: 31. https://doi.org/10.1186/1476-4598-5-31

[35] QI Y, LI H, SHENOY V, LI Q, WONG F et al. Moderate cardiac-selective overexpression of angiotensin II type 2 receptor protects cardiac functions from ischaemic injury. Exp Physiol 2012; 97: 89-101. https://doi.org/10.1113/expphysiol.2011.060673

[36] SUN L, WANG W, XIAO W, LIANG H, YANG Y et al. Angiotensin II induces apoptosis in intestinal epithelial cells through the AT2 receptor, GATA- 6 and the Bax pathway. Biochem Biophys Res Commun 2012; 424: 663-668. https:// doi.org/10.1016/j.bbrc.2012.07.003

[37] WANG X, LU J, KHAIDAKOV M, MITRA S, DING Z et al. Delineation of the effects of angiotensin type 1 and 2 receptors on HL-1 cardiomyocyte apoptosis. Apoptosis 2012; 17: 908-915. https://doi.org/10.1007/s10495-012-0721-6

[38] WANG C, QIAN X, SUN X, CHANG Q. Angiotensin II increases matrix metalloproteinase 2 expression in human aortic smooth muscle cells via AT1R and ERK1/2. Exp Biol Med (Maywood) 2015; 240: 1564-1571. https://doi. org/10.1177/1535370215576312

[39] MIURA S, KARNIK SS. Ligand-independent signals from angiotensin II type 2 receptor induce apoptosis. EMBO J 2000; 19: 4026-4035. https://doi.org/10.1093/emboj/19.15.4026

[40] LIU X, GAO RW, LI M, SI CF, HE YP et al. The ROS derived mitochondrial respirstion not from NADPH oxidase plays key role in Celastrol against angiotensin II-mediated HepG2 cell proliferation. Apoptosis 2016; 21: 1315-1326. https:// doi.org/10.1007/s10495-016-1294-6

[41] DU H, LIANG Z, ZHANG Y, JIE F, LI J et al. Effects of angiotensin II type 2 receptor overexpression on the growth of hepatocellular carcinoma cells in vitro and in vivo. PLoS One 2013; 8: e83754. https://doi.org/10.1371/journal. pone. 0083754

[42] FRIDAY BB, ADJEI AA. Advances in targeting the Ras/Raf/ MEK/Erk mitogen-activated protein kinase cascade with MEK inhibitors for cancer therapy. Clin Cancer Res 2008; 14 : 342-346. https://doi.org/10.1158/1078-0432.CCR-07-4790

[43] JI Y, WANG Z, LI Z, ZHANG A, JIN Y et al. Angiotensin II Enhances Proliferation and Inflammation through AT1/ PKC/NF-kB Signaling Pathway in Hepatocellular Carcinoma Cells. Cell Physiol Biochem 2016; 39: 13-32. https://doi. org/10.1159/000445602 
[44] MCCUBREY JA, STEELMAN LS, CHAPPELL WH, ABRAMS SL, WONG EW et al. Roles of the Raf/MEK/ERK pathway in cell growth, malignant transformation and drug resistance. Biochim Biophys Acta 2007; 1773: 1263-1284. https://doi.org/10.1016/j.bbamcr.2006.10.001
[45] BALASUBRAMANIAN S, HURLEY LH, NEIDLE S. Targeting G-quadruplexes in gene promoters: a novel anticancer strategy? Nature reviews. Nat Rev Drug Discov 2011; 10 : 261-275. https://doi.org/10.1038/nrd3428 